\title{
Developments in cancer vaccines for hepatocellular carcinoma
}

\author{
Luigi Buonaguro ${ }^{1} \cdot$ HEPAVAC Consortium
}

Received: 16 March 2015 / Accepted: 30 May 2015 / Published online: 21 June 2015

(C) Springer-Verlag Berlin Heidelberg 2015

\begin{abstract}
Hepatocellular carcinoma (HCC) accounts for about $6 \%$ of all new cancers diagnosed worldwide and represents one of the leading causes of cancer-related death globally in men and women, respectively. The overall prognosis for HCC patients is poor, especially in the majority of patients with more advanced stage of disease. Indeed, in such cases immunotherapeutic strategies may represent a novel and effective tool. A few immunotherapy trials conducted for HCC have provided divergent results, urging the scientific community to explore additional paths to improve efficacy of immunotherapeutic approaches. The "Cancer Vaccine development for Hepatocellular Carcinoma"HEPAVAC Consortium has been funded by the EU within the FP7 with the goal of developing a novel therapeutic peptide-based cancer vaccine strategy for HCC including both "off-the-shelf" and personalized antigens. This will be one of the very few vaccine trials for HCC and the first multi-epitope, multi-target and multi-HLA allele therapeutic cancer vaccine for such a frequent and aggressive
\end{abstract}

This paper is a Focussed Research Review based on a presentation given at the Twelfth Meeting of the Network Italiano per la Bioterapia dei Tumori (NIBIT) on Cancer BioImmunotherapy, held in Siena, Italy, 9th-11th October 2014. It is part of a series of Focussed Research Reviews and meeting report in Cancer Immunology, Immunotherapy.

The members of HEPAVAC Consortium are listed in the "Appendix" section.

Luigi Buonaguro

1.buonaguro@istitutotumori.na.it

1 Laboratory of Molecular Biology and Viral Oncology, Istituto Nazionale per lo Studio e la Cura dei Tumori, "Fondazione Pascale" - Istituto di Ricerca e Cura a Carattere Scientifico (IRCCS), Naples, Italy disease with a hitherto high unmet medical need. Feasibility, safety and biological efficacy will be evaluated in a randomized, controlled European multicenter phase I/II clinical trial.

Keywords Hepatocellular carcinoma - Cancer vaccine . Tumor-associated epitopes · HEPAVAC · HLA ligandome · NIBIT 2014

$\begin{array}{ll}\text { Abbreviations } \\ \text { AFP } & \text { Alpha fetoprotein } \\ \text { APVAC } & \text { Actively personalized vaccine } \\ \text { ASR } & \text { Age-standardized } \\ \text { CIITA } & \text { Class II (major histocompatibility complex) } \\ & \text { transactivator } \\ \text { CRC } & \text { Colorectal cancer } \\ \text { DCs } & \text { Dendritic cells } \\ \text { dTc } & \text { Designer T cells } \\ \text { EGF } & \text { Epidermal growth factor } \\ \text { EU } & \text { European Union } \\ \text { FoR } & \text { Frequency of recurrence } \\ \text { FP7 } & \text { Framework Programme 7 } \\ \text { GB } & \text { Glioblastoma } \\ \text { GM-CSF } & \text { Granulocyte-monocyte } \\ & \text { factor } \\ \text { CPC3 } & \text { Glypican 3 } \\ \text { HBV } & \text { Hepatitis B virus } \\ \text { HCC } & \text { Hepatocellular carcinoma } \\ \text { HCV } & \text { Hepatitis C virus } \\ \text { HEPAVAC } & \text { Cancer Vaccine development for Hepatocel- } \\ \text { IFN } \gamma & \text { lular Carcinoma } \\ \text { IGFR } & \text { Interferon gamma } \\ \text { IL-12 } & \text { Interleukin-12 } \\ \text { LSECs } & \text { Liver sinusoidal endothelial cells } \\ & \end{array}$




$\begin{array}{ll}\text { MoA } & \text { Mode of action } \\ \text { OS } & \text { Overall survival } \\ \text { PD } & \text { Progressive disease } \\ \text { PFS } & \text { Progression-free survival } \\ \text { PR } & \text { Partial response } \\ \text { Pts } & \text { Patients } \\ \text { QoL } & \text { Quality of life } \\ \text { Ras MAPK } & \text { Mitogen-activated protein kinases } \\ \text { RCC } & \text { Renal cell cancer } \\ \text { RFA } & \text { Radiofrequency ablation } \\ \text { RFS } & \text { Recurrence-free survival } \\ \text { SD } & \text { Stable disease } \\ \text { TAAs } & \text { Tumor-associated antigens } \\ \text { TACE } & \text { Transcatheter chemoembolization } \\ \text { TAEs } & \text { Tumor-associated epitopes } \\ \text { TILs } & \text { Tumor infiltrating lymphocytes } \\ \text { TtFR } & \text { Time to first recurrence } \\ \text { TUMAPs } & \text { Tumor-associated peptides } \\ \text { VEGF } & \text { Vascular growth factor }\end{array}$

\section{HCC epidemiology}

Hepatocellular carcinoma (HCC) is the most common primary liver malignancy, with both viral and nonviral origin, accounting for about $6 \%$ of all new cancer cases diagnosed worldwide (nearly 750,000 new cases/year). It is the third and the fifth leading cause of cancer-related death globally in men and women, respectively. The age-standardized incidence rate (ASR) per 100,000 men per year for HCC greatly varies in different regions. It is about 9.5 in Southern Europe and Northern America but increases to 31.9 and 22.2 in Eastern and Southeastern Asia, respectively (http:// globocan.iarc.fr/).

There is a growing incidence of HCC worldwide mostly due to long-lasting chronic HBV and HCV infections acquired in the last century, although incidence and mortality rates are greatly heterogeneous [1-4].

The most frequent risk factors for HCC include chronic viral hepatitis (types B and C), alcohol intake and aflatoxin exposure. However, even though their geographical distribution is uneven, more than $50 \%$ of $\mathrm{HCC}$ cases can be attributed to HBV infection, more than $30 \%$ can be attributed to HCV infection, and approximately $15 \%$ can be associated with other causes.

\section{Treatment options and prognosis}

The overall prognosis for HCC patients is poor, with a dismal 5-year survival rate of approximately 5-6 \% [5, 6]. Indeed, the number of medical interventions tested in $\mathrm{HCC}$ is significantly lower compared to other cancers with a high prevalence/incidence worldwide (e.g., lung, breast, colorectal cancers). Therefore, a limited range of therapies are available to be used in the management of HCC according to the extent and severity of liver disease.

Surgery (i.e., liver resection and transplantation) represents the first choice of treatment for HCC in patients with early tumors on an intention-to-treat perspective, achieving a survival of $60-80 \%$ at 5 years $[7,8]$. However, $70 \%$ of patients undergoing liver resection show tumor recurrence within 5 years characterized by either intrahepatic metastases or appearance of de novo tumor lesions [9]. Several adjuvant treatments to prevent recurrence have been evaluated, but none of these has provided a clear body of evidence for efficacy [10].

However, the majority of patients are diagnosed when disease is not treatable by surgical strategies anymore and can be approached only with loco-regional therapies which include a large panel of choices [11]. Local ablation is the first option for HCC patients at early stages, and radiofrequency ablation (RFA) provides up to a 40-70\% survival rate at 5 years [12]. Indeed, RFA has been considered as a possible alternative to surgical resection in HCC patients with single small lesions, but contrasting clinical outcomes have been reported [13, 14]. Transcatheter chemoembolization (TACE) is the first option for the treatment of intermediate stage and unresectable HCC [15]. Partial response is observed in almost $50 \%$ of patients treated with TACE showing a delayed tumor progression, although survival benefits have not been fully established [16].

Finally, systemic therapeutic options in advanced unresectable HCC are limited to sorafenib which is the only approved therapy confirmed to provide a limited increase of 2.3-2.8 months in survival [17-20]. Different studies have addressed the HCC pathogenesis in order to identify possible additional targets for systemic therapies, suggesting that multiple concurrent molecular mechanisms or pathways are involved (e.g., vascular growth factor (VEGF) signaling; epidermal growth factor (EGF) signaling; Ras MAPK signaling; insulin-like growth factor receptor (IGFR) signaling) [21, 22]. Such studies strongly support the idea that, indeed, combination strategies or targeted therapies are needed to possibly improve clinical outcomes [23].

\section{Immunotherapy approaches for HCC}

The limited number of therapeutic options for advancedstage HCC with effective clinical outcome urges the scientific community to develop new therapeutic tools. In particular, immunotherapy and cancer vaccines may provide 
Table 1 Immunotherapy and cancer vaccine approaches for HCC

\begin{tabular}{|c|c|c|c|c|}
\hline Strategy & Treatment & No. of enrolled pts. & Finding & Refs. \\
\hline \multirow[t]{4}{*}{ Immunotherapy } & GM-CSF + IFN- $\gamma$ & 15 & $\begin{array}{l}\text { OS at } 26 \text { weeks } 40 \% \\
\text { OS at } 52 \text { weeks } 20 \%\end{array}$ & {$[25]$} \\
\hline & IL-12 & 9 & SD $29 \%$ & {$[26]$} \\
\hline & 111In-TIL & 3 & PR $66 \%$ & [28] \\
\hline & Activated autologous lymphocytes & 150 & $\begin{array}{l}\text { FoR } 59 \% \text { versus } 77 \% \\
\text { TtFR } 48 \% \text { versus } 33 \% \text { at } 3 \text { y; } \\
38 \text { versus } 22 \% \text { at } 5 \text { y } \\
\text { RFS } 65 \% \text { versus } 58 \% \text { at } 5 y\end{array}$ & [29] \\
\hline \multirow[t]{6}{*}{ Cancer Vaccines } & AFP peptides & 6 & PD 6/6—OS $9.3 \mathrm{mo}$ & {$[30]$} \\
\hline & AFP_DC pulsed & 10 & PD 9/10—OS 10.4 mo & {$[31]$} \\
\hline & Autologous tumor lysate-DC pulsed & 31 & $\begin{array}{l}\text { PR 4/31-OS } 18 \mathrm{mo} \\
\text { SD } 17 / 31-O S 13 \mathrm{mo} \\
\text { PD } 10 / 31-2.8 \mathrm{mo}\end{array}$ & {$[33]$} \\
\hline & tumor cell line lysate-DC pulsed & 35 & $\begin{array}{l}\text { PR 1/35-OS N/A } \\
\text { SD 6/35-OS N/A } \\
\text { PD 18/35-OS N/A } \\
\text { N/A 14/35-OS N/A }\end{array}$ & [34] \\
\hline & GPC3 peptides & 33 & $\begin{array}{l}\text { PR } 1 / 33-O S 12 \mathrm{mo} \\
\text { SD 19/33-OS } 13.4 \mathrm{mo} \\
\text { PD } 13 / 33-O S 7.4 \mathrm{mo}\end{array}$ & [36] \\
\hline & Telomerase peptide & 40 & $\begin{array}{l}\text { SD } 17 / 40 \text {-OS } 11 \text { months } \\
\text { PD } 20 / 40 \text { N/A } 3 / 40\end{array}$ & [38] \\
\hline
\end{tabular}

111In-TIL indium-111-labeled tumor-infiltrating lymphocytes, $A F P$ alpha fetoprotein, $D C$ dendritic cells, FoR frequency of recurrence, $G M$ - $C S F$ granulocyte-monocyte colony-stimulating factor, GPC3 glypican 3, IFN- $\gamma$ interferon gamma, $I L-12$ interleukin-12, mo months, $N / A$ not available, $O S$ overall survival, $P D$ progressive disease, $P R$ partial response, $p t s$ patients, $R F S$ recurrence-free survival, $S D$ stable disease, $T t F R$ time to first recurrence, $y$ years

a significant benefit over current treatment options either in advanced stages or in the adjuvant setting. However, a few immunotherapy trials conducted to date for HCC have provided only modest results (reviewed in [24]). Cytokines have been used to boost anti-tumor immune responses or increase the tumor immunogenicity [25, 26]. Alternatively, tumor-infiltrating lymphocytes (TILs) or activated peripheral blood lymphocytes have been used for intratumoral infusion [27-29].

Similarly, the number of therapeutic clinical cancer vaccine trials performed for HCC is extremely small and results are not satisfactory. $\mathrm{T}$ cell epitopes specific for alpha fetoprotein (AFP), used alone or loaded on autologous DCs, have been shown to elicit a specific and transient CD8 + T cell response [30-32]. Alternatively, only limited improvements in clinical outcomes have been observed in HCC patients using autologous DCs pulsed ex vivo with a lysate either of the autologous tumor [33] or of the hepatoblastoma cell line HepG2 [34, 35]. A clinical trial based on peptide vaccine targeting glypican 3 (GPC3) has shown a positive correlation between GPC3-specific CTL frequencies and the median overall survival $[36,37]$. Finally, a combination of low-dose cyclophosphamide with a telomerase peptide (GV1001) vaccination did not show any antitumor efficacy [38] (Table 1).

\section{Improving immunotherapy strategies for HCC}

The limited efficacy of cancer vaccine in HCC may be ascribed to different possible causes, one of these being the strong intrinsic hepatic immunosuppressive microenvironment induced by several residing cell subsets, including hepatocytes, liver sinusoidal endothelial cells (LSECs), Kupffer cells and liver dendritic cells (DCs) [39-41]. Consequently, combinatorial strategies are needed to address and counterbalance such an immunosuppressive environment in order to improve clinical outcome of cancer vaccine protocols.

An additional cause of the observed limited efficacy is the restricted number of known HCC-specific tumor-associated antigens (TAAs) to be used for eliciting an effective immune response (reviewed in [41]).

New and specific tumor-associated antigens (TAAs) and/ or tumor-associated epitopes (TAEs) can be identified by integration of multiple high-throughput "omics" technologies (reviewed in [42]) and validated by immunoinformatics algorithms [43-47]. In this path, the ultimate frontier is represented by the analysis of naturally processed tumorassociated epitopes (so-called HLA ligandome) [48], which has allowed us to identify new epitopes for different tumors 


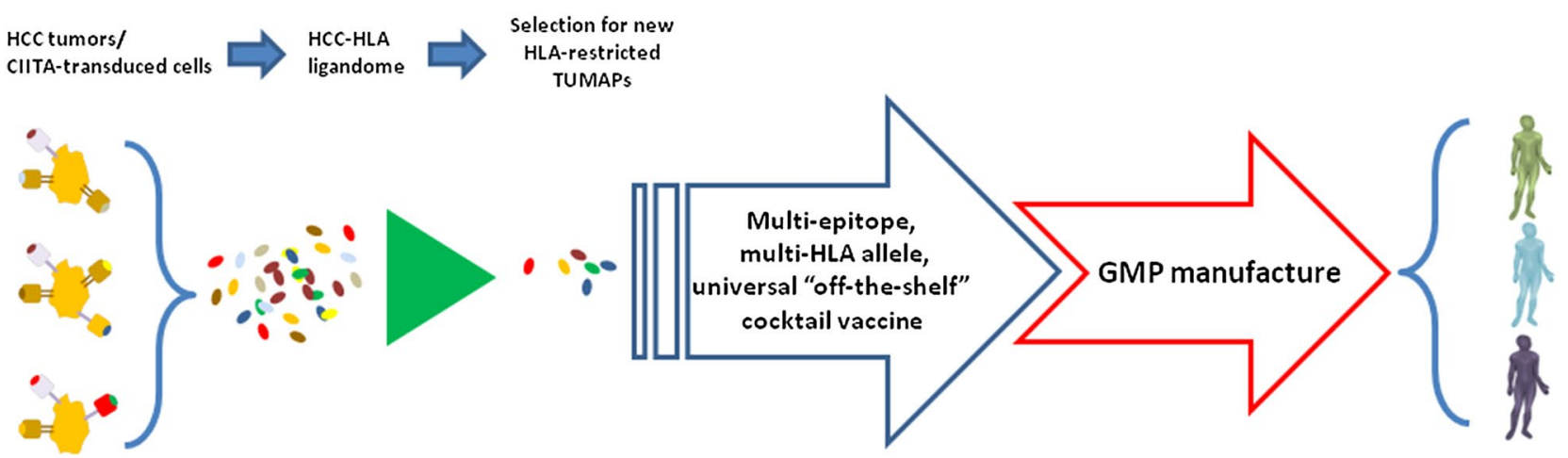

HCC patients

Fig. 1 Strategy and technical process for development of a multitarget, multi-epitope and multi-HLA allele vaccine for hepatocellular carcinoma. HCC tumors as well as CIITA-transduced cells will be analyzed by combined proteomics and genomics strategies for

(e.g., glioblastoma-GB [49], renal cell cancer-RCC as well as colorectal cancer-CRC) employed in cancer vaccines phase I/II human clinical trials [50, 51].

\section{Cancer Vaccine development for Hepatocellular Carcinoma: HEPAVAC}

Along such a path of multiple high-throughput "omics" technologies applied to cancer vaccinology, the collaborative project "Cancer Vaccine development for Hepatocellular Carcinoma-HEPAVAC" has been funded by the EU within the FP7. The main goal of HEPAVAC is to develop a novel therapeutic cancer vaccine strategy for HCC in order to address factors which are believed to have hampered the efficacy of previously tested cancer vaccines (www.hepavac.eu).

In particular, HEPAVAC will generate an "off-the-shelf" vaccine including a cocktail of newly identified HLA class I- and class II-restricted tumor-associated peptides (TUMAPs) among those naturally presented on the membrane of either primary HCC tumor cells or of CIITAtransduced hepatoma cell lines (Fig. 1). The HCC HLA ligandome will be discovered by the XPRESIDENTTM technology (the "Tuebingen approach" [48, 52]), and tumor-specific peptides will be selected according to their broad expression in HCC tumors and low-to-no expression in normal tissues. After immunological validation, such "off-the-shelf" vaccine will be ready to use for any eligible HCC patient characterized by that specific HLA allele background. The vaccination protocol will be complemented, in a subset of vaccinees, by an actively personalized vaccine (APVAC) approach. The latter will include patient-specific naturally processed and presented peptides expression of tumor-specific TUMAPs. Shared peptides will be identified, validated immunologically and selected (up to 40) for combination in the HCC universal "off-the-shelf" vaccine

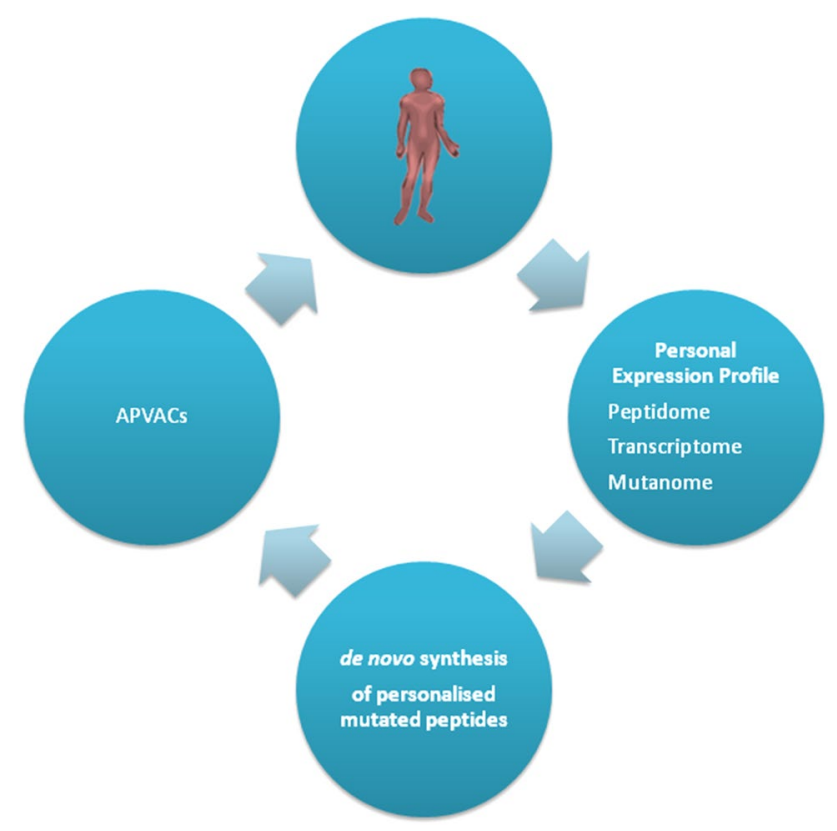

Fig. 2 Strategy of APVAC generation. Each HCC tumors will be analyzed straight after surgery for expression of tumor-specific HLA ligands, and patient-specific peptides will be selected and synthesized de novo. Each patient will then receive a personalized vaccine (APVAC) adapted to his/her own tumor

selected according to integration of genomics, transcriptomics and HLA ligandomics analyses (Fig. 2).

Both the "off-the-shelf" and the personalized vaccine will be combined with a novel and potent RNA-based immunomodulator (RNAdjuvant ${ }^{\circledR}$ ) which is based on a noncoding, long-chain RNA molecule able to induce balanced, long-lasting immune responses resulting in a strong anti-tumor activity [53]. 


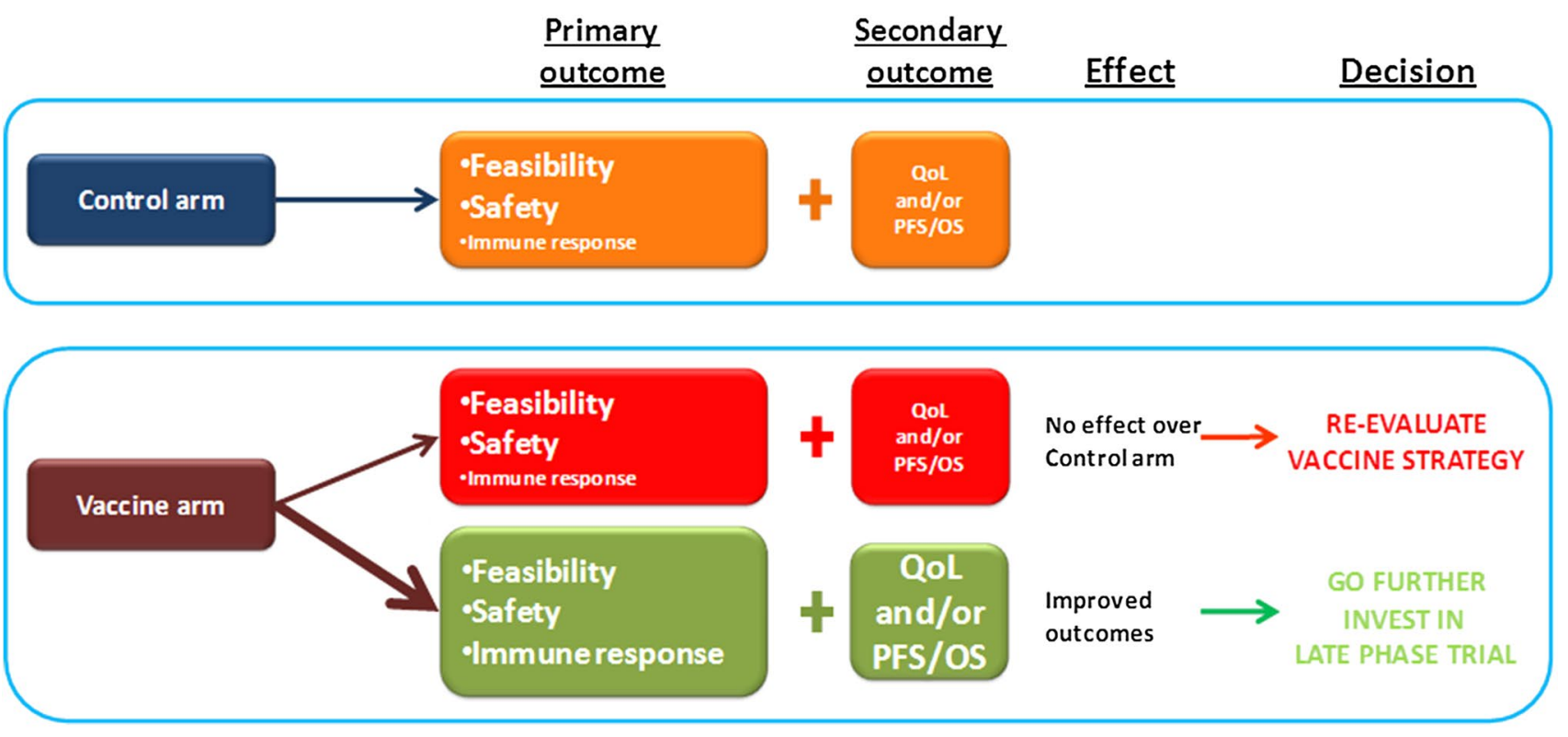

Fig. 3 Scheme of the expected results in the HEPAVAC clinical trial and resulting decisions for further development

Furthermore, to describe the mechanism of action $(\mathrm{MoA})$ and indicate a proof of concept, the project will include a comprehensive $\mathrm{T}$ cell immunomonitoring and biomarker program enabling the development of new tools to monitor and predict the clinical outcome of patients.

The HEPAVAC vaccine will be finally evaluated in a randomized controlled European multicenter phase I/II clinical trial to assess feasibility, safety and biological efficacy (Fig. 3).

This will be one of the very few vaccine trials for HCC and the first multi-epitope, multi-target and multi-HLA allele therapeutic cancer vaccine for such a frequent and aggressive disease.

\section{Concluding remarks}

$\mathrm{HCC}$ is an aggressive disease with a high unmet medical need. In advanced stages, each of the currently available treatments is palliative and immunotherapy has been only partially explored with hitherto limited clinical outcomes. The novel cancer vaccine strategy currently developed by the FP7 EU-funded HEPAVAC Consortium (Grant Agreement No. 602893) will provide results extremely relevant to the cancer vaccine field and hopefully warrant unprecedented clinical outcomes with great beneficial effects for HCC patients.

Acknowledgments The study was funded by European 7th Framework Programme (EU FP7) Project Cancer Vaccine development for Hepatocellular Carcinoma-HEPAVAC (Grant No. 602893).
Conflict of interest The authors declare that they have no competing interest.

\section{Appendix}

Members of the HEPAVAC Consortium are:

Sarah Kutscher, Andrea Mayer, Toni Weinschenk, Phillip Mueller, Harpreet Singh-Jasuja, Immatics Biotechnologies $\mathrm{GmbH}$, Tuebingen, Germany;

Roberto Accolla, Giovanna Tosi, Dept. Surgical and Morphological Sciences, Univ. dell'Insubria, Varese, Italy;

Yuk T. Ma, David Adams, NIHR Biomedical Research Unit in Liver Disease, School of Immunity and Infection, University of Birmingham, Birmingham, UK;

Danila Valmori, Maha Ayyoub, Institut National de la Santé et de la Recherché Medicale (INSERM) Research Unit (UMR) 1102, Saint Herblain, France;

Regina Heidenreich, CUREVAC GmbH, Tuebingen, Germany;

Alfred Koenigsrainer, Markus Loeffler, Department of Surgery, Eberhard Karls University, Tuebingen, Germany;

Hans-Georg Rammensee, Dept of Immunology, Eberhard Karls Univ., Tuebingen, Germany;

Bruno Sangro, Liver Unit, Clinica Universidad de Navarra, and Centro de Investigacion Biomedica en Red de Enfermedades Hepaticas y Digestivas (CIBEREHD), Pamplona, Spain; 
Sven Francque, Division of Gastroenterology and Hepatology, Antwerp University Hospital, Edegem, Belgium; Maria Tagliamonte, Annacarmen Petrizzo, Maria Lina Tornesello, Franco M. Buonaguro, Luigi Buonaguro, Mol. Biol and Viral Oncogenesis Unit, Ist. Naz. Tumori "Pascale," Napoli, Italy;

Francesco Izzo, Liver Surgery Unit, Ist. Naz. Tumori "Pascale," Napoli, Italy.

\section{References}

1. Bosetti C, Levi F, Boffetta P, Lucchini F, Negri E, La VC (2008) Trends in mortality from hepatocellular carcinoma in Europe, 1980-2004. Hepatology 48:137-145

2. Jemal A, Siegel R, Ward E, Hao Y, Xu J, Murray T, Thun MJ (2008) Cancer statistics, 2008. CA Cancer J Clin 58:71-96

3. Tanaka H, Imai Y, Hiramatsu N, Ito Y, Imanaka K, Oshita M, Hijioka T, Katayama K, Yabuuchi I, Yoshihara H, Inoue A, Kato M, Takehara T, Tamura S, Kasahara A, Hayashi N, Tsukuma $\mathrm{H}$ (2008) Declining incidence of hepatocellular carcinoma in Osaka, Japan, from 1990 to 2003. Ann Intern Med 148:820-826

4. Chang MH, You SL, Chen CJ, Liu CJ, Lee CM, Lin SM, Chu HC, Wu TC, Yang SS, Kuo HS, Chen DS (2009) Decreased incidence of hepatocellular carcinoma in hepatitis B vaccinees: a 20-year follow-up study. J Natl Cancer Inst 101:1348-1355

5. European Association for the Study of the Liver EOfRaToC (2012) EASL-EORTC clinical practice guidelines: management of hepatocellular carcinoma. J Hepatol 56:908-943

6. Fong ZV, Tanabe KK (2014) The clinical management of hepatocellular carcinoma in the United States, Europe, and Asia: a comprehensive and evidence-based comparison and review. Cancer 120:2824-2838

7. Llovet JM, Schwartz M, Mazzaferro V (2005) Resection and liver transplantation for hepatocellular carcinoma. Semin Liver Dis $25: 181-200$

8. Mazzaferro V, Llovet JM, Miceli R, Bhoori S, Schiavo M, Mariani L, Camerini T, Roayaie S, Schwartz ME, Grazi GL, Adam R, Neuhaus P, Salizzoni M, Bruix J, Forner A, De CL, Cillo U, Burroughs AK, Troisi R, Rossi M, Gerunda GE, Lerut J, Belghiti J, Boin I, Gugenheim J, Rochling F, Van HB, Majno P (2009) Predicting survival after liver transplantation in patients with hepatocellular carcinoma beyond the Milan criteria: a retrospective, exploratory analysis. Lancet Oncol 10:35-43

9. Roayaie S, Blume IN, Thung SN, Guido M, Fiel MI, Hiotis S, Labow DM, Llovet JM, Schwartz ME (2009) A system of classifying microvascular invasion to predict outcome after resection in patients with hepatocellular carcinoma. Gastroenterology 137:850-855

10. Samuel M, Chow PK, Chan Shih-Yen E, Machin D, Soo KC (2009) Neoadjuvant and adjuvant therapy for surgical resection of hepatocellular carcinoma. Cochrane Database Syst Rev (1):CD001199. doi:10.1002/14651858.CD001199.pub2

11. Lencioni R, Crocetti L (2012) Local-regional treatment of hepatocellular carcinoma. Radiology 262:43-58

12. Lencioni R, Cioni D, Crocetti L, Franchini C, Pina CD, Lera J, Bartolozzi C (2005) Early-stage hepatocellular carcinoma in patients with cirrhosis: long-term results of percutaneous imageguided radiofrequency ablation. Radiology 234:961-967

13. Chen MS, Li JQ, Zheng Y, Guo RP, Liang HH, Zhang YQ, Lin XJ, Lau WY (2006) A prospective randomized trial comparing percutaneous local ablative therapy and partial hepatectomy for small hepatocellular carcinoma. Ann Surg 243:321-328
14. Huang J, Yan L, Cheng Z, Wu H, Du L, Wang J, Xu Y, Zeng Y (2010) A randomized trial comparing radiofrequency ablation and surgical resection for HCC conforming to the Milan criteria. Ann Surg 252:903-912

15. Bruix J, Sherman M (2011) Management of hepatocellular carcinoma: an update. Hepatology 53:1020-1022

16. Oliveri RS, Wetterslev J, Gluud C (2011) Transarterial (chemo)embolisation for unresectable hepatocellular carcinoma. Cochrane Database Syst Rev (3):CD004787. doi:10.1002/14651858.CD004787.pub2

17. Chang YS, Adnane J, Trail PA, Levy J, Henderson A, Xue D, Bortolon E, Ichetovkin M, Chen C, McNabola A, Wilkie D, Carter CA, Taylor IC, Lynch M, Wilhelm S (2007) Sorafenib (BAY 43-9006) inhibits tumor growth and vascularization and induces tumor apoptosis and hypoxia in RCC xenograft models. Cancer Chemother Pharmacol 59:561-574

18. Wilhelm SM, Carter C, Tang L, Wilkie D, McNabola A, Rong H, Chen C, Zhang X, Vincent P, McHugh M, Cao Y, Shujath J, Gawlak S, Eveleigh D, Rowley B, Liu L, Adnane L, Lynch M, Auclair D, Taylor I, Gedrich R, Voznesensky A, Riedl B, Post LE, Bollag G, Trail PA (2004) BAY 43-9006 exhibits broad spectrum oral antitumor activity and targets the RAF/MEK/ERK pathway and receptor tyrosine kinases involved in tumor progression and angiogenesis. Cancer Res 64:7099-7109

19. Siegel AB, Olsen SK, Magun A, Brown RS Jr (2010) Sorafenib: where do we go from here? Hepatology 52:360-369

20. Chan SL, Mok T, Ma BB (2012) Management of hepatocellular carcinoma: beyond sorafenib. Curr Oncol Rep 14:257-266

21. Farazi PA, DePinho RA (2006) Hepatocellular carcinoma pathogenesis: from genes to environment. Nat Rev Cancer 6:674-687

22. Villanueva A, Newell P, Chiang DY, Friedman SL, Llovet JM (2007) Genomics and signaling pathways in hepatocellular carcinoma. Semin Liver Dis 27:55-76

23. Villanueva A, Hernandez-Gea V, Llovet JM (2013) Medical therapies for hepatocellular carcinoma: a critical view of the evidence. Nat Rev Gastroenterol Hepatol 10:34-42

24. Greten TF, Wang XW, Korangy F (2015) Current concepts of immune based treatments for patients with HCC: from basic science to novel treatment approaches. Gut 64:842-848

25. Reinisch W, Holub M, Katz A, Herneth A, Lichtenberger C, Schoniger-Hekele M, Waldhoer T, Oberhuber G, Ferenci P, Gangl A, Mueller C (2002) Prospective pilot study of recombinant granulocyte-macrophage colony-stimulating factor and interferon-gamma in patients with inoperable hepatocellular carcinoma. J Immunother 25:489-499

26. Sangro B, Mazzolini G, Ruiz J, Herraiz M, Quiroga J, Herrero I, Benito A, Larrache J, Pueyo J, Subtil JC, Olague C, Sola J, Sadaba B, Lacasa C, Melero I, Qian C, Prieto J (2004) Phase I trial of intratumoral injection of an adenovirus encoding interleukin-12 for advanced digestive tumors. J Clin Oncol 22:1389-1397

27. Shi M, Zhang B, Tang ZR, Lei ZY, Wang HF, Feng YY, Fan ZP, Xu DP, Wang FS (2004) Autologous cytokine-induced killer cell therapy in clinical trial phase I is safe in patients with primary hepatocellular carcinoma. World J Gastroenterol 10:1146-1151

28. Takayama T, Makuuchi M, Sekine T, Terui S, Shiraiwa H, Kosuge T, Yamazaki S, Hasegawa H, Suzuki K, Yamagata M (1991) Distribution and therapeutic effect of intraarterially transferred tumor-infiltrating lymphocytes in hepatic malignancies. A preliminary report. Cancer 68:2391-2396

29. Takayama T, Sekine T, Makuuchi M, Yamasaki S, Kosuge T, Yamamoto J, Shimada K, Sakamoto M, Hirohashi S, Ohashi Y, Kakizoe T (2000) Adoptive immunotherapy to lower postsurgical recurrence rates of hepatocellular carcinoma: a randomised trial. Lancet 356:802-807

30. Butterfield LH, Ribas A, Meng WS, Dissette VB, Amarnani S, Vu HT, Seja E, Todd K, Glaspy JA, McBride WH, Economou JS 
(2003) T-cell responses to HLA-A*0201 immunodominant peptides derived from alpha-fetoprotein in patients with hepatocellular cancer. Clin Cancer Res 9:5902-5908

31. Butterfield LH, Ribas A, Dissette VB, Lee Y, Yang JQ, De la RP, Duran SD, Hernandez J, Seja E, Potter DM, McBride WH, Finn R, Glaspy JA, Economou JS (2006) A phase I/II trial testing immunization of hepatocellular carcinoma patients with dendritic cells pulsed with four alpha-fetoprotein peptides. Clin Cancer Res 12:2817-2825

32. Bray SM, Vujanovic L, Butterfield LH (2011) Dendritic cellbased vaccines positively impact natural killer and regulatory $\mathrm{T}$ cells in hepatocellular carcinoma patients. Clin Dev Immunol 2011:249281. doi:10.1155/2011/249281

33. Lee WC, Wang HC, Hung CF, Huang PF, Lia CR, Chen MF (2005) Vaccination of advanced hepatocellular carcinoma patients with tumor lysate-pulsed dendritic cells: a clinical trial. J Immunother 28:496-504

34. Palmer DH, Midgley RS, Mirza N, Torr EE, Ahmed F, Steele JC, Steven NM, Kerr DJ, Young LS, Adams DH (2009) A phase II study of adoptive immunotherapy using dendritic cells pulsed with tumor lysate in patients with hepatocellular carcinoma. Hepatology 49:124-132

35. El Ansary M, Mogawer S, Elhamid SA, Alwakil S, Aboelkasem F, Sabaawy HE, Abdelhalim O (2013) Immunotherapy by autologous dendritic cell vaccine in patients with advanced HCC. J Cancer Res Clin Oncol 139:39-48

36. Sawada Y, Yoshikawa T, Nobuoka D, Shirakawa H, Kuronuma T, Motomura Y, Mizuno S, Ishii H, Nakachi K, Konishi M, Nakagohri T, Takahashi S, Gotohda N, Takayama T, Yamao K, Uesaka K, Furuse J, Kinoshita T, Nakatsura T (2012) Phase I trial of a glypican-3-derived peptide vaccine for advanced hepatocellular carcinoma: immunologic evidence and potential for improving overall survival. Clin Cancer Res 18:3686-3696

37. Tada Y, Yoshikawa T, Shimomura M, Sawada Y, Sakai M, Shirakawa H, Nobuoka D, Nakatsura T (2013) Analysis of cytotoxic $\mathrm{T}$ lymphocytes from a patient with hepatocellular carcinoma who showed a clinical response to vaccination with a glypican3-derived peptide. Int J Oncol 43:1019-1026

38. Greten TF, Forner A, Korangy F, N'Kontchou G, Barget N, Ayuso C, Ormandy LA, Manns MP, Beaugrand M, Bruix J (2010) A phase II open label trial evaluating safety and efficacy of a telomerase peptide vaccination in patients with advanced hepatocellular carcinoma. BMC Cancer 10:209

39. Thomson AW, Knolle PA (2010) Antigen-presenting cell function in the tolerogenic liver environment. Nat Rev Immunol 10:753-766

40. Bowen DG, Zen M, Holz L, Davis T, McCaughan GW, Bertolino $\mathrm{P}$ (2004) The site of primary T cell activation is a determinant of the balance between intrahepatic tolerance and immunity. J Clin Invest 114:701-712

41. Buonaguro L, Petrizzo A, Tagliamonte M, Tornesello ML, Buonaguro FM (2013) Challenges in cancer vaccine development for hepatocellular carcinoma. J Hepatol 59:897-903

42. O’Meara MM, Disis ML (2011) Therapeutic cancer vaccines and translating vaccinomics science to the global health clinic: emerging applications toward proof of concept. OMICS 15:579-588

43. Rammensee H, Bachmann J, Emmerich NP, Bachor OA, Stevanovic S (1999) SYFPEITHI: database for MHC ligands and peptide motifs. Immunogenetics 50:213-219

44. Singh H, Raghava GP (2001) ProPred: prediction of HLA-DR binding sites. Bioinformatics 17:1236-1237

45. Reche PA, Glutting JP, Reinherz EL (2002) Prediction of MHC class I binding peptides using profile motifs. Hum Immunol 63:701-709

46. Guan P, Hattotuwagama CK, Doytchinova IA, Flower DR (2006) MHCPred 2.0: an updated quantitative T-cell epitope prediction server. Appl Bioinformatics 5:55-61

47. Bachinsky MM, Guillen DE, Patel SR, Singleton J, Chen C, Soltis DA, Tussey LG (2005) Mapping and binding analysis of peptides derived from the tumor-associated antigen survivin for eight HLA alleles. Cancer Immun 5:6

48. Singh-Jasuja H, Emmerich NP, Rammensee HG (2004) The Tubingen approach: identification, selection, and validation of tumor-associated HLA peptides for cancer therapy. Cancer Immunol Immunother 53:187-195

49. Dutoit V, Herold-Mende C, Hilf N, Schoor O, Beckhove P, Bucher J, Dorsch K, Flohr S, Fritsche J, Lewandrowski P, Lohr J, Rammensee HG, Stevanovic S, Trautwein C, Vass V, Walter S, Walker PR, Weinschenk T, Singh-Jasuja H, Dietrich PY (2012) Exploiting the glioblastoma peptidome to discover novel tumourassociated antigens for immunotherapy. Brain 135:1042-1054

50. Kuttruff S, Weinschenk T, Schoor O, Lindner J, Kutscher S, Maurer D, Mayer-Mokler A, Ludwig J, Nowara E, Torday L, Cseh J, Hohler T, Hitre E, Maughan T, Adams R, Mayer F, Reinhardt C, Singh H, Walter S (2012) Immune responses and association with clinical outcome of advanced colorectal cancer patients with the multi-peptide vaccine IMA910. J Clin Oncol [2012 ASCO Annual Meeting Proceedings (suppl; abstr 2522]

51. Walter S, Weinschenk T, Stenzl A, Zdrojowy R, Pluzanska A, Szczylik C, Staehler M, Brugger W, Dietrich PY, Mendrzyk R, Hilf N, Schoor O, Fritsche J, Mahr A, Maurer D, Vass V, Trautwein C, Lewandrowski P, Flohr C, Pohla H, Stanczak JJ, Bronte V, Mandruzzato S, Biedermann T, Pawelec G, Derhovanessian E, Yamagishi H, Miki T, Hongo F, Takaha N, Hirakawa K, Tanaka H, Stevanovic S, Frisch J, Mayer-Mokler A, Kirner A, Rammensee HG, Reinhardt C, Singh-Jasuja H (2012) Multipeptide immune response to cancer vaccine IMA901 after single-dose cyclophosphamide associates with longer patient survival. Nat Med 18:1254-1261

52. Weinschenk T, Gouttefangeas C, Schirle M, Obermayr F, Walter S, Schoor O, Kurek R, Loeser W, Bichler KH, Wernet D, Stevanovic S, Rammensee HG (2002) Integrated functional genomics approach for the design of patient-individual antitumor vaccines. Cancer Res 62:5818-5827

53. Heidenreich R, Jasny E, Kowalczyk A, Lutz J, Probst J, Baumhof P, Scheel B, Voss S, Kallen KJ, Fotin-Mleczek M (2015) A novel RNA-based adjuvant combines strong immunostimulatory capacities with a favorable safety profile. Int J Cancer 137:372-384 